九州大学学術情報リポジトリ

Kyushu University Institutional Repository

Ground Beetles (Coleoptera, Caraboidea) Caught by a Light Trap During Ten Years

Yahiro, Katsuro

Yano, Koj i

https://doi.org/10.5109/2608

出版情報 : ESAKIA. 37，pp.57-69，1997-09-30. Entomological Laboratory，Faculty of Agriculture， Kyushu University

バージョン :

権利関係 : 


\title{
Ground Beetles (Coleoptera, Caraboidea) Caught by a Light Trap During Ten Years ${ }^{1)}$
}

\author{
Katsuro Yahiro \\ Lake Biwa Museum, \\ Kusatsu, Shiga, 525 Japan \\ and \\ Kôji YANO ${ }^{2)}$ \\ Laboratory of Insect Management, Faculty of Agriculture. \\ Yamaguchi University, Yamaguchi, 753 Japan
}

\begin{abstract}
Species composition and long-term fluctuation of ground beetles attracted to a light trap operated at Yamaguchi University Farm for 10 years were analyzed. A total of 77 species of Omophronidae, Carabidae, and Brachinidae were caught. Three species, Stenolophusdifficilis, Anoplogenius cyanescens, and Acupalpus inornatus, were most frequently caught. The fauna found was compared with those in nearby agroecosystems, and the original habitats from whence the ground beetles flew were inferred. The annual activity of the beetles during the 10 years is illustrated. Increasing, decreasing, or periodically varying abundance during the 10 years were found for different beetle species. Environmental factors seems to have no influence on the catch.

Key words: Biology, ground beetles, light trap, species composition. long-term fluctuation.
\end{abstract}

\section{Introduction}

Many studies on light trap collections of insects made in various habitats have been done, and the influence of environmental factors such as moonlight, temperature, rainfall. or wind on catches of insects has been discussed often (Williams, 1940; Landin. 1968; Bowden, 1973; Garrido et al., 1979). Long-term operation of light traps has sometimes been carried out (Williams, 1939; Shimaji, 1973, 1974; Hagen, 1976; Nakamura. 198 1: Fuse, 1987; Gyotoku, 1990; Wolda, 1992), but the results of such collections have rarely been reported in detail. In Japan, light trap collecting in paddy fields, vegetable

1) Faunal and biological studies on the insects of paddy fields in Asia. XLII.

2) Present address: Asakura-cho 1 1-23, Yamaguchi, 753 Japan. 
fields, and orchards has been done at agricultural or horticultural experiment stations for many years to forecast the occurrence of pest species. These traps, however, are operated only during certain periods of the year and concern only a limited number of target pest species. Natural enemies or non-target species are rarely studied by these trapping programs.

A light trap set at Yamaguchi University Farm in 1980 has been operating continuosly in order to learn the long-term fluctuation of insects attracted from surrounding areas including paddy fields and other agroecosystems. The collection consequently contains pests, natural enemies and other insects.

In the present paper, the ground beetles caught by the trap during the first 10 years were analyzed to learn their long-term fluctuation and the beetle faunistics of the area concerned, including agroecosystems. Ground beetles have received much attention owing to their high diversity and predaceous food habit in various habitats (Thiele. 1977: Luff, 1987), although only limited data from light trap collections have been presented (Frost, 1958; Vanhercke et al., 1981; Ishitani, 1996). All available information on each insect group is needed to provide for better management of insect pests in agroecosystems, and the ground beetles seem to be particulary important (Yasumatsu et al., 1981).

We have been working on the insect fauna of paddy fields and the surrounding environments along the same lines (Yano, 1978), and have surveyed the ground beetles in paddy fields (Yahiro et al., 1992), a vineyard (Yano et al., 1989), a forage crop field (Ishitani et al., 1994), and an adjoining forest (Yahiro et al., 1990) on the Yamaguchi University Farm. Similar studies on ground beetles have been made on river banks in the same area (Ishitani et. al., in prep.), providing related informations.

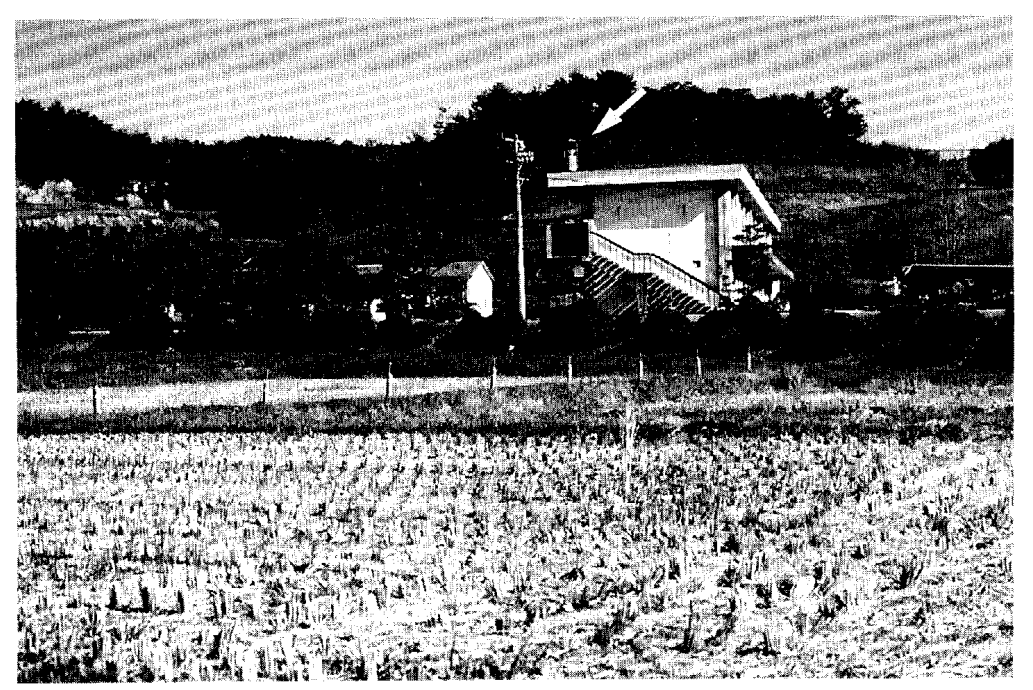

Fig. 1. Light trap set at Yamaguchi University Farm (harvested paddy fields in the foreground and orchards in the background; arrow indicates the trap). 


\section{Materials and Methods}

The trap used in this study was set on the roof of the building on the University Farm in September, 1980 (Fig. 1). The trap (Ikeda Rika Co.: MT-7) ran automatically and the insects caught over seven days were obtained separately each day. The source of light is a 60-watt electric light bulb at a height of $9.3 \mathrm{~m}$ from the ground. Lighting hours were set for 12 (18:00 -- 6:00) and a plate of Vapona was put in each collecting cage (a total of seven cages) to kill the insects caught. Paper bags were set inside the cages to collect all insects including minute ones and to allow for their easy removal from the cages. The bulb and Vapona were regularly changed once each month and once every two or three months, respectively. The insects in the seven cages were removed from the cages weekly and preserved temporarily in paper triangles or paper bags dated daily before processing.

The trap used is the same as those used at agricultural experiment stations in all the prefectures in Japan for the insect pest forecasting program. It was not placed in paddy fields as originally intended, because of a technical problem. The vegetation of the area around the trap is illustrated in Fig. 2. Paddy fields, crop fields, orchards, forests, ponds, and yards are located within $300 \mathrm{~m}$ of the trap, and it is difficult to determine the original habitat whence the insects came. As expected, agricultural and forest insects were collected together with aquatic insects and other non-target species. There were no

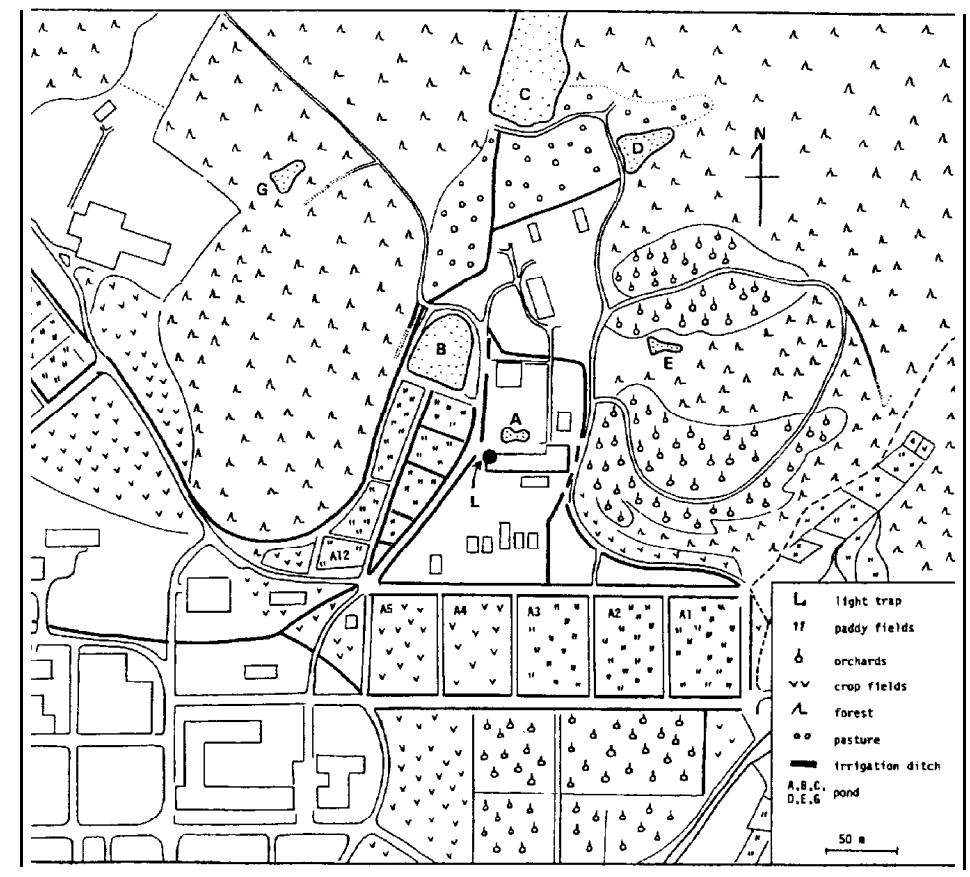

Fig. 2. Map of study area in Yamaguchi University Farm showing the vegetation around the light trap. 
Table 1. Number of individual ground beetles caught by a light trap (Yamaguchi University Farm, 1981-1990). ${ }^{1)}$

\begin{tabular}{|c|c|c|c|c|c|c|c|c|c|c|c|}
\hline \multirow{2}{*}{ Omophronidae } & \multicolumn{2}{|c|}{19811982} & 1983 & \multirow[t]{2}{*}{1984} & 1985 & \multirow{2}{*}{\multicolumn{2}{|c|}{19861987}} & 1988 & 19891990 & \multicolumn{2}{|c|}{ Tot a I } \\
\hline & & & & & & & & & & & \\
\hline Omophron aequalis Morawitz & 0 & 0 & 1 & 0 & 0 & 0 & 0 & 0 & 0 & 0 & 1 \\
\hline \multicolumn{12}{|l|}{ Carabidae } \\
\hline Campalita chinense (Kirby) & 0 & 0 & 0 & 1 & 0 & 2 & 0 & 0 & 0 & 1 & 4 \\
\hline Scartites acutidens Chaudoif & 0 & 0 & 0 & 0 & 0 & 0 & 0 & 0 & 1 & 0 & 1 \\
\hline Clivina westwoodi Putzeys* & 0 & 0 & 0 & 1 & 0 & 0 & 1 & 0 & 0 & 2 & 4 \\
\hline C. castanea Westwood & 1 & 2 & 5 & 1 & 1 & 1 & 3 & 5 & 78 & 2 & 99 \\
\hline Dyschirius ordinatus Bates* & 0 & 0 & 0 & 0 & 1 & 1 & 0 & 0 & 0 & 1 & 3 \\
\hline Trechus ephippiatus Bates & 23 & 12 & 53 & 0 & 27 & 10 & 14 & 33 & 14 & 9 & 195 \\
\hline Lasiotrechus discus (Fabricius) & 0 & 0 & 0 & 0 & 0 & 0 & 0 & 0 & 0 & 1 & 1 \\
\hline Paratachys pallescens (Bates) & 0 & 0 & 2 & 1 & 8 & 11 & 1 & 1 & 3 & 7 & 34 \\
\hline P. fasciatus fasciatus (Motschulsky) & 0 & 2 & 0 & 0 & 0 & 0 & 0 & 0 & 0 & 0 & 2 \\
\hline Tachyura laetifica (Bates) & 23 & I 00 & 77 & 121 & 106 & 155 & 99 & 112 & 84 & 58 & 1025 \\
\hline T. exarata (Bates) & 0 & 4 & 3 & 1 & 0 & 6 & & 5 & 1 & 0 & 20 \\
\hline Bembidion morawitzi Csiki & 3 & 1 & 2 & 2 & 2 & 2 & 6 & 3 & 0 & 0 & 21 \\
\hline B. chloreum Bates & 6 & 25 & a & 2 & 4 & 12 & & 18 & 7 & 3 & 93 \\
\hline B. consummatum Bates & 1 & 0 & 2 & 0 & 0 & 1 & 11 & 1 & 0 & 7 & 23 \\
\hline B. niloticum batesi Putzeys & 0 & 0 & 1 & 0 & 5 & 0 & 1 & 6 & 9 & 12 & 34 \\
\hline B. semilunium Netolitzky & 4 & 0 & 0 & 0 & 3 & 0 & 0 & 0 & 0 & 0 & 7 \\
\hline Caelostomus picipes japonicus (Tschitscheri & ine) 1 & 3 & 1 & 3 & 1 & 1 & 1 & 2 & 0 & 0 & 13 \\
\hline Pterostichus planicollis (Motschulsky) & 0 & 0 & 0 & 0 & 0 & 0 & 0 & 1 & 0 & 0 & 1 \\
\hline P. sulcitarsis Morawitz & 0 & 0 & 0 & 0 & 0 & 1 & 0 & 0 & 0 & 0 & 1 \\
\hline P. prolongatus Morawitz & 0 & 0 & 0 & 0 & 0 & 0 & 1 & 0 & 0 & 0 & 1 \\
\hline$P$. longinquus Bates & 5 & 27 & 1 & 31 & 1 & 1 & 5 & 24 & 15 & 8 & 118 \\
\hline P. rotundangulus Morawitz & 0 & 0 & 2 & 0 & 1 & 0 & 0 & 0 & 1 & 0 & 4 \\
\hline P.microcephalus (Motschulsky) & 0 & 0 & 0 & 0 & 1 & 0 & 0 & 0 & 1 & 0 & 2 \\
\hline Platynus magnus (Bates) & 16 & 71 & 59 & 27 & 17 & 18 & 24 & 21 & 8 & 12 & 273 \\
\hline P. protensus (Morawitz) & 1 & 5 & a & 17 & 4 & 2 & 5 & $Q$ & 9 & a & 69 \\
\hline Colpodes Jampros B ates & 1 & 3 & 6 & 2 & 1 & 1 & 1 & 1 & 1 & 2 & 19 \\
\hline C. buchanani Hope & 2 & 5 & 3 & 3 & 8 & 1 & 5 & 4 & 4 & 0 & 35 \\
\hline Dolichus halensis (Schaller) & 0 & 0 & 0 & 1 & 1 & 0 & 3 & 0 & 3 & 0 & 8 \\
\hline Agonum chalcomus (Bates) & 0 & 8 & 9 & 1 & 0 & 3 & 10 & 6 & 2 & 6 & 45 \\
\hline A. leucopus (Bates) & 0 & 1 & 0 & 6 & 5 & 0 & 0 & 0 & 1 & 0 & 13 \\
\hline Synuchus callitheres callitheres (Bates)* & 0 & 0 & 1 & 0 & 0 & 0 & 1 & 0 & 0 & 0 & 2 \\
\hline Amara nipponica Habu & 1 & 1 & 3 & 1 & 0 & 0 & 0 & 0 & 0 & 0 & 6 \\
\hline A. gigantea (Motschulsky) & 2 & 5 & 5 & 2 & 4 & 3 & 1 & 8 & 4 & 3 & 37 \\
\hline Anisodactylus signatus (Panzer) & 2 & 1 & 1 & 1 & 2 & 1 & 2 & 2 & 3 & 1 & 16 \\
\hline A. tricuspidatus Morawitz & 0 & 0 & 0 & 0 & 0 & 0 & 1 & 1 & 0 & 0 & 2 \\
\hline A. punctatipennis Morawitz & 6 & 1 & 4 & 3 & 5 & 1 & 8 & 11 & 13 & 21 & 73 \\
\hline Harpalus capito Morawitz & 1 & 4 & 1 & 1 & 1 & 2 & 2 & 0 & 2 & 2 & 16 \\
\hline H. jureceki (Jedlicka) & 52 & 63 & 91 & 104 & 93 & 88 & 101 & 105 & 167 & 119 & 983 \\
\hline H. eous Tschitscherine & 8 & 11 & 26 & 43 & 22 & 16 & 15 & 31 & 27 & 21 & 220 \\
\hline H. sinicus Hоре & 22 & 31 & 55 & 48 & 19 & 24 & 38 & 54 & 91 & 61 & 443 \\
\hline H. tridens Morawitz & 6 & 7 & 5 & 3 & 11 & 17 & 14 & 16 & 18 & 12 & 109 \\
\hline Platymetopus flavilabris (Fabricius) & 0 & 0 & 1 & 0 & 0 & 0 & 0 & 0 & 0 & 0 & 1 \\
\hline Acupalpus inornatus Bates & 177 & 183 & 120 & 358 & 361 & 184 & 222 & 766 & 436 & 480 & 3287 \\
\hline Stenolophus propinquus Morawitz & 0 & 1 & 2 & 1 & 0 & 1 & 0 & 0 & 0 & 0 & 5 \\
\hline S. iridicolor Redtenbacher & 3 & 2 & 11 & 7 & 5 & 0 & 0 & 0 & 1 & 0 & 29 \\
\hline S. quinquepustulatus (Wiedemann) & 1 & 2 & 3 & 4 & 2 & 0 & 0 & 4 & 0 & 0 & 16 \\
\hline S. difficilis (Hope) & 1745 & 1826 & 1416 & 2805 & 7231 & 4119 & 7206 & $6 \quad 5919$ & 474710 & 09684 & 47982 \\
\hline Anoplogenius cyanescens (Hope) & 171 & 322 & 516 & 533 & 365 & 174 & 521 & 622 & 607 & 605 & 4436 \\
\hline
\end{tabular}




\begin{tabular}{|c|c|c|c|c|c|c|c|c|c|c|c|}
\hline Species & 1981 & 1982 & 1983 & 1984 & 1985 & 1986 & 1987 & 1968 & 1989 & 1990 & Total \\
\hline Badister nigriceps Morawitz* & 7 & 7 & 7 & 5 & 3 & 4 & 3 & 3 & 1 & 5 & 45 \\
\hline Pent agoni ca daimaiella Bates & $\mathbf{0}$ & 0 & 0 & 0 & 0 & 0 & 1 & 2 & 0 & 0 & 3 \\
\hline Aephni di usadel i oi des (MacLeay) & 1 & 1 & 0 & 0 & 3 & 1 & 0 & $\mathbf{0}$ & 0 & 1 & 7 \\
\hline Di schi ssusmi randus Bates & 0 & 0 & 0 & 0 & 1 & 0 & 0 & 0 & 0 & 0 & 1 \\
\hline Epomis nigricans (Wiedemann) & 0 & 0 & 0 & 0 & 0 & 0 & 0 & 0 & 0 & 3 & 3 \\
\hline Chl aeni us vari i corni s Morawitz & 2 & 1 & 1 & 1 & $\mathbf{0}$ & 0 & 1 & 0 & 1 & 3 & 10 \\
\hline C. circumdatus Brulle & $\mathbf{0}$ & 1 & 0 & $\mathbf{0}$ & 0 & 1 & 0 & 0 & 0 & 0 & 2 \\
\hline C. micans (Fabricius) & 41 & 34 & 33 & 46 & 57 & 38 & 47 & 59 & 45 & 56 & 456 \\
\hline C. virgulifer Chaudoir & 2 & 2 & 2 & 5 & 3 & 1 & 3 & 8 & 6 & 3 & 35 \\
\hline Lithochlaenius noguchii (Bates) & 0 & 0 & 0 & 2 & $\mathbf{0}$ & 0 & 1 & 1 & 0 & 1 & 5 \\
\hline Peronomerus nigrinus $\mathrm{B}$ a le $\mathrm{s}$ * & 0 & 0 & 0 & 0 & $\mathbf{0}$ & 0 & 0 & 0 & 0 & 1 & 1 \\
\hline Lachnocrepis prolixa (Bates) & 0 & $\mathbf{0}$ & 1 & 1 & $\mathbf{0}$ & 0 & 1 & 0 & 0 & 0 & 3 \\
\hline Archicolliuris bi macul at a nipponica Habu & 1 & 0 & 0 & 0 & $\mathbf{0}$ & 1 & 0 & 0 & 0 & 2 & 4 \\
\hline Anomotarus stigmula (Chaudoir) & 0 & 0 & 0 & 0 & $\mathbf{0}$ & 0 & 1 & 0 & 0 & 0 & 1 \\
\hline Coptodera japonica Bates & 0 & 0 & 0 & 0 & 1 & 0 & 0 & 0 & 0 & 1 & 2 \\
\hline C. subapi cal is Putzeys & 0 & 0 & 0 & 0 & 0 & 0 & 1 & 0 & 0 & 0 & 1 \\
\hline Parena cavi penni s (Bates) & 0 & 1 & 1 & 0 & 1 & 0 & 1 & 1 & 0 & 0 & 5 \\
\hline Lachnolebia cribricollis (Morawitz) & 0 & 0 & 0 & 0 & 0 & 0 & 0 & 0 & 2 & 0 & 2 \\
\hline Parena latecincta (Bates) & 4 & 9 & 7 & 9 & 10 & 7 & 17 & 6 & 14 & 10 & 93 \\
\hline Lebia calycophora Schmidt-Gobel & 0 & 1 & 0 & 0 & 0 & $\mathbf{0}$ & 0 & 0 & 0 & 1 & 2 \\
\hline L. dupl ex Bates & 0 & 0 & 0 & 0 & 0 & $\mathbf{0}$ & 1 & 0 & 0 & 0 & 1 \\
\hline L. retrofasciata Motschulsky & 1 & 0 & 0 & 0 & 0 & 0 & 0 & 0 & 0 & 0 & 1 \\
\hline L. i dae Bates & 0 & 0 & 1 & 0 & 0 & 0 & 0 & 0 & 0 & 0 & 1 \\
\hline Apri st usgrandi s Andrewes & 0 & 0 & 0 & 0 & 0 & 0 & 0 & 2 & 1 & 0 & 3 \\
\hline Droni usproi xus Bates & 0 & 0 & 0 & 1 & 0 & $\mathbf{0}$ & 0 & 1 & 3 & 4 & 9 \\
\hline Drypraj aponi ca Bates & 0 & 1 & 1 & 0 & 0 & $\mathbf{0}$ & 0 & 0 & 0 & 0 & 2 \\
\hline \multicolumn{12}{|l|}{ Brachinidae } \\
\hline Brachi nusscot onedes Redtenbacher & 0 & 0 & 0 & 0 & 0 & 1 & 0 & 0 & 0 & 0 & 1 \\
\hline Brachi nus i nconpt us Bates & 0 & 0 & 0 & 0 & 0 & 0 & 0 & 0 & 1 & 0 & 1 \\
\hline No. of species & 35 & 40 & 44 & 40 & 40 & 38 & 43 & 38 & 39 & 33 & 77 \\
\hline Total & 2343 & 2877 & 2560 & 4205 & 8397 & 4913 & 8408 & 7874 & 6432 & 12523 & 60532 \\
\hline
\end{tabular}

1) Species with asterisks are new records for Yamaguchi Prefecture.

other lights around the trap except for one room of the building. which was usually lighted for few hours after sunset.

The collection obtained from January, 198 1, to December, 1990, was analyzed in this study; the trap has continued to operate since then.

\section{Results and Discussion}

\section{Species composition}

A total of 60,532 individuals belonging to 77 species of Omophronidae, Carabidae, and Brachinidae were collected by the light trap (Table 1). Seven species among them had not been recorded from Yamaguchi Prefecture (Tanaka, 1988). The 77 species obtained represent $26 \%$ of the species recorded from the prefecture. The number of collected species should be evaluated in light of the fact that less collecting effect for ground beetles has been undertaken by light traps than by other collecting methods; in addition, there are flightless species in this insect group. Although ground beetles are 
Table 2. Number of individuals of dominant ground beetle species in 4 different habitats and those in a light trap (Yamaguchi Univ. Farm). ${ }^{1)}$

\begin{tabular}{|c|c|c|c|c|c|}
\hline Speci es & For est" & Vi neyard" & Paddy fields ${ }^{4}$ & For agecrop & field ${ }^{5)}$ Light trap ${ }^{8)}$ \\
\hline Carabus japonicus & 338 & 0 & 6 & 0 & 0 \\
\hline C. dehaanii & 73 & 0 & 2 & 0 & 0 \\
\hline Platynus magnus & 1 & 0 & 370 & 0 & 273 \\
\hline Agonum chalcomus & 0 & 0 & 80 & 123 & 45 \\
\hline Amara chalcites & 1 & 716 & 481 & 0 & 0 \\
\hline Anisodactylus punctatipennis & 0 & 904 & 10 & 7 & 73 \\
\hline Harpaius tridens & 8 & 1106 & 234 & 97 & 109 \\
\hline H. jureceki & 0 & 10 & 346 & 68 & 963 \\
\hline H. sinicus & 1 & 219 & 117 & 646 & 443 \\
\hline H. eous & 1 & 116 & $\mathbf{0}$ & 231 & 220 \\
\hline Stenolophus difficilis & 0 & 0 & 4 & 0 & 47982 \\
\hline Anoplogenius cyanescens & 0 & 0 & 4 & 0 & 4436 \\
\hline Acupalpus inornatus & 0 & 0 & 2 & 0 & 3287 \\
\hline Haplochlaenius costiger & 123 & 40 & 15 & 0 & 0 \\
\hline Chlaenius micans & 61 & 479 & 95 & 125 & 456 \\
\hline C. naeviger & 6.8 & 1 & 2 & 0 & 0 \\
\hline Pheropsophus jessoensis & 4 & 427 & 761 & 1 & 0 \\
\hline
\end{tabular}

well able to fly to electric lights (Larochelle, 1973), the insects are not strongly attracted to light compared to other insect groups. Ishitani (1996) collected 37 species of ground beetles from a river bank in Hiroshima City by pitfall traps, while only 5 species (14\%) were collected by a light trap on the same bank, this despite the year-round operation of the pitfall trap versus a much more limited light trap effort (3 occasions only).

The three most frequently caught species amounted to 55,705 individuals, or $92.0 \%$ of the total figure. These three dominant species were Stenolophus difficilis, Anoplogenius cyanescens, and Acupalpus inornatus, in decreasing order. Stenolophus difficilis was the most frequently caught, representing $79.3 \%$ of the total.

Only one to ten individuals each of 43 species were caught over the ten years. Twelve species numbered over 100 individuals, including the three dominant species. These data indicate that ground beetles are not strongly attracted to light since there are 75 species of these three families in the agroecosystems near the trap: 53 in paddy fields and adjoining levees (Yahiro et al., 1992), 26 in a vineyard (Yano, et al., 1989), 29 in a forage crop field (Ishitani et al., 1994), and 33 in a forest (Yahiro et al., 1990).

The numbers of species common to the light trap collection and the nearby habitats are $27,13,15$, and 11, concerning paddy fields, a vineyard, a forage crop field, and a forest, respectively. The high similarity is with paddy fields, followed by the forage crop field. vineyard, and forest. The forage crop field and vineyard were about $300 \mathrm{~m}$ away from the trap. It is supposed that the trap site, comprising farmyards, orchards, and crop fields, has fauna similar to those of the forage crop field and vineyard. Faunal studies on the orchards located east of the trap are required to clalify the matter.

The numbers of individuals of the dominant beetle species caught by the light trap and found in the surrounding habitats are shown in Table 2. The three dominant species in 
the light trap collection are not major in any habitats. These species seem to live in yards. orchards, or other crop fields where vegetables are usually planted. Harpalus jureceki and Platynus magnus were apparently derived from paddy fields. Amarachalcites and Harpalus tridens, two other dominant species in paddy fields, were not or rarely found in the light trap collections. Paddy fields are situated closely to the light trap (Fig. 2), but about $12 \mathrm{~m}$ below the trap. This suggests that either the light trap is not good for enumerating the ground beetle fauna of paddy fields or the trap is too high to attract the beetles. Frost (1958) reported that carabids showed little difference in selecting light traps at different heights; however his highest trap was at 15 feet $(4.6 \mathrm{~m})$, lower than the present trap level.

\section{Long-term fluctuation}

As shown in Table 1, 33 to 44 species were caught each year. Among the 77 species caught altogether, 21 species were caught every year, 15 species in 5-9 years, and 41 species in 2-4 years. The total number of individuals caught per year increased from the first three or four years towards the following years (Table 1, Fig. 3 ); the reason for this is not known.

Annual occurrences of the 15 major species are shown in Fig. 4. The ground beetles showed increases, decreases, or periodic fluctuations in abundance. Four species. Anisodactylus punctatipennis, Acupalpus inomatus, Harpalus jureceki, and Stenolophus difficilis showed an increase in the number of individuals (Fig. 4A). Three species. Stenolophus quinquepustulatus, Amara nipponica, and Colpodeslampros, showed a decrease (Fig. 4B). One species, Chlaenius micans, showed little fluctuation (Fig. 4C).

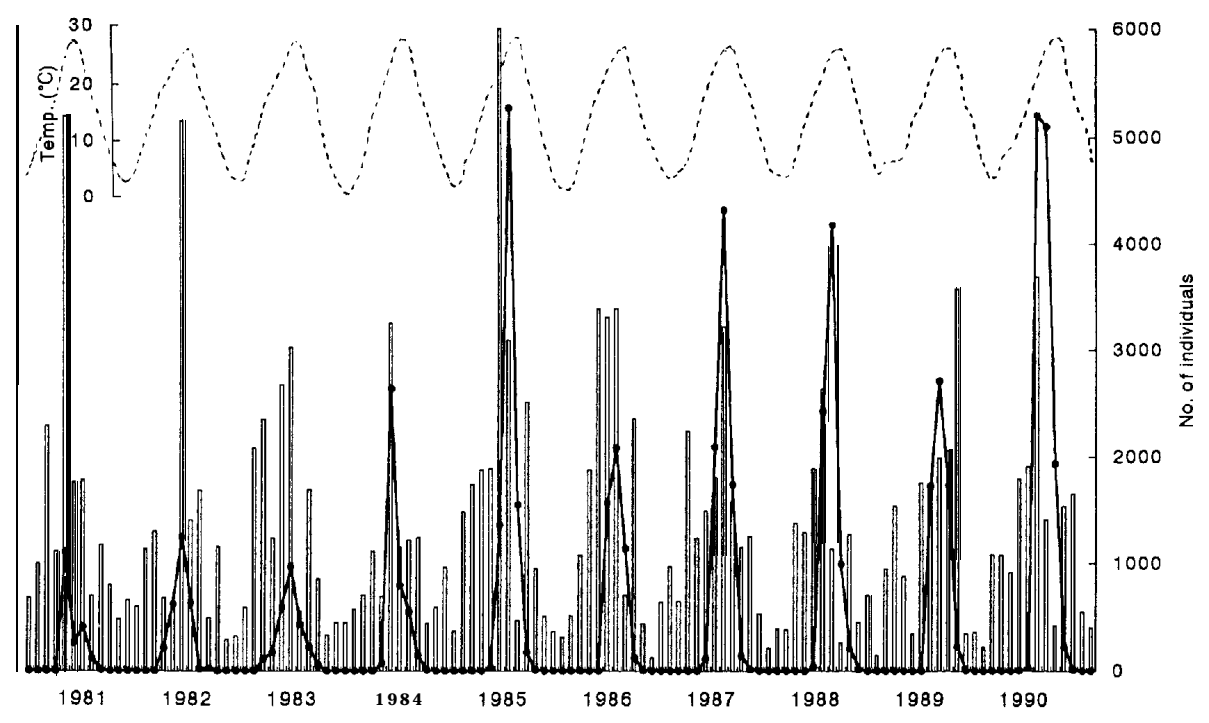

Fig. 3. Monthly number of ground beetles caught by a light trap (Yamaguchi Univ. Farm, 198 1- 1990) (Solid line: monthly number of individuals; dotted line: monthly mean temperature; open line: monthly rainfall). 

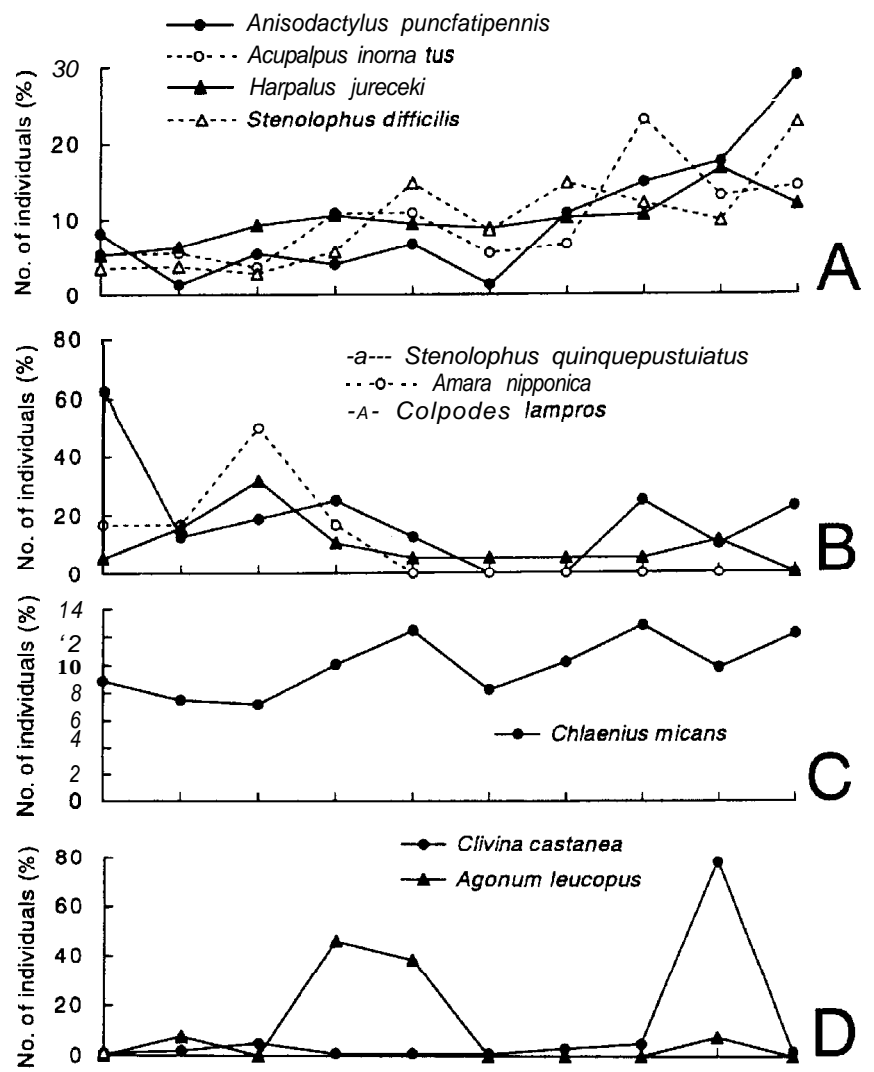

$\rightarrow$ Pterostichus longinquus

.--o...Caelostomus picipes japonicus

-A- Tachyura exarata
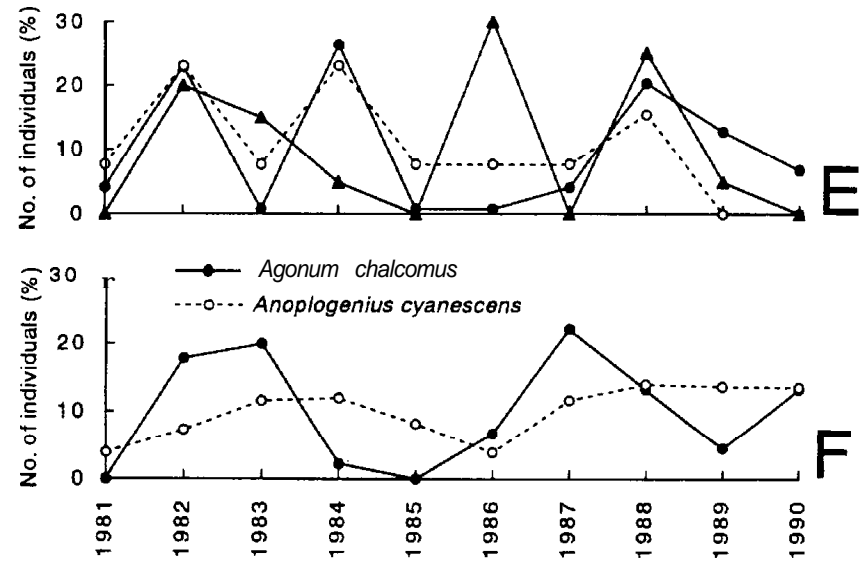

Fig. 4. Annual occurrence of the 15 major species of ground beetles caught by a light trap (Yamaguchi Univ. Farm, 198 1- 1990). Percent of individuals per total number of individuals caught in 10 years is expressed. 

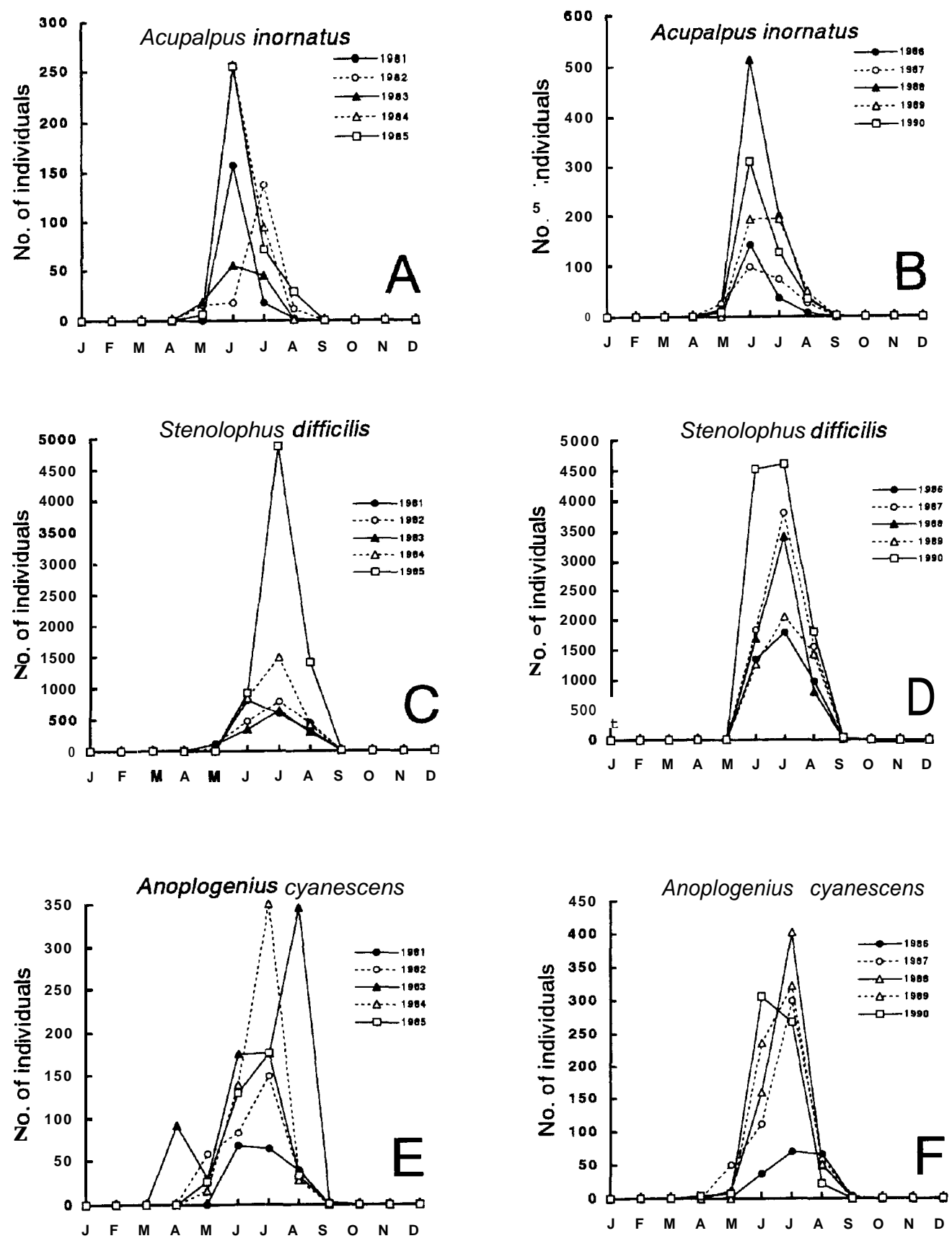

Fig. 5. Seasonal abundance of the three dominant species of ground beetles caught by a light trap (Yamaguchi Univ. Farm) (A, C, E: 1981-1985, B, D, F: 1986-1990). 
Two species, Clivina castanea and Agonum leucopus, showed distinct peaks in 1984 and 1989, respectively (Fig. 4D). Three species, Pterostichus longinquus, Caelostomus picipes japonicus, and Tachyura exarata, showed periodic fluctuations, with three distinct peaks during the 10 years (Fig. 4E). Two species, Agonum chalcomus and Anoplogenius cyanescens, drastically decreased twice or three times (Fig. 4F). Factors influencing these various fluctuations are unknown.

Previous reports on the long-term fluctuation of ground beetles as revealed by pitfall trapping showed relatively little fluctuation in abundance from year to year (Luff, 1973. 1980, 1982). The present result show rather extensive fluctuations even though the surrounding fields did not change during the study period. The difference in sampling method, pitfall versus light trap, may be the reason; light trap collections are more sensitive to environmental factors.

Detailed long-term light trap records for insects are scarce except for a few agricultural pests. Hagen (1976) found that large populations of the western bean cutworm. Loxagrotis albicosta, occurred at intervals of 6-8 years during 14 years of light trapping. He could not predict flights from one year to the next based on the data obtained. Miyashita (197 1) illustrated the fluctuation of light trap catches of the rice stem borer. Chilo suppressalis, in Japan based on a IO-year survey. He found three types of fluctuation: a downward phase, a steady level, and an upward phase. These two papers do not lend themselves to generalization since various cultural factors have a role in the abundance of the species. It may be said, however, that some insect species other than pests also fluctuate in annual abundance at intervals of several years. This is true for some species illustrated in Fig. 4 in the present study.

The seasonal abundance of the three dominant species during the 10 years of the study is illustrated in Fig. 5. Acupalpus inornatus and Stenolophus difficilis showed fixed patterns of occurrence regarding their peak periods. The former species had a peak in June every year except for 1982, when it came in July. The latter species had a peak in July every year. The peak of occurrence of Anoplogenius cyanescens was seen in June. July, or August, depending on the year. The periods of the peak of these three species were not variable as mentioned, and sharp seasonal peaks are recognized. The relative height of the seasonal peak in these species was, however, varied over the 10 years through an order of magnitude. Since light trap collections are generally not steady owing to climatic conditions and other factors, this difference is not surprising, though the precise reason is unknown. Wolda $(1978,1980)$ found that species with a sharp seasonal peak were more variable in abundance from year to year than species which do not have such sharp peaks. The present species seem to follow this pattern.

In the winters (November-March) during the 10 years, a total of 7 individuals of 4 species were attracted. These were Tachyura laetifica, Bembidion chloreum, Stenolophus difficilis, and Badister nigriceps. These collections indicate that adult overwintering occurs in these species. Carabids generally don't fly until the daily maximum temperature rises above $16^{\circ} \mathrm{C}$ (van Huizen, 1979).

\section{Influence of environmental factors on abundance}

The flight of ground beetles is greatly influenced by temperature, rain, wind. and the physiological age of the beetles (van Huizen, 1979; Lövei and Sunderland, 1996). Fig. 3 shows the monthly number of ground beetles caught, monthly rainfall. and the mean 
monthly temperatures during the 10 years studied. Although the number of beetle individuals increased in later years as mentioned, no definite relation between the number and these two climatic factors was found. The coefficients of correlation between monthly number of beetles and both monthly total rainfall and monthly mean temperature were 0.44 and 0.56 , respectively, indicating no definite relationships.

\section{Acknowledgments}

We are grateful to Mr. S. Hamasaki and many undergraduate students of the Laboratory of Insect Management for their help in making the collections and other ways. and to the staff of Yamaguchi University Farm for the use of the farm. Our thanks also go to Dr. M. Ishitani, Towa Kagaku Co., Ltd., for the literature. We wish to express our gratitude to Dr. M. J. Grygier of the Lake Biwa Museum for his critical comments on the manuscript.

\section{References}

Bowden, J., 1973. The influence of moonlight on catches of insects in light-traps in Africa. Part 1. The moon and moonlight. Bull. ent. Res., 63: 113-128.

Frost, S. W., 1958. Insects attracted to light traps placed at different heights. J. econ. Ent., 51: 550-551.

Fuse, H., 1987. Light-trap survey of moth fauna at the Shonai Branch Yamagata Prefecture Agricultural Experiment Station with seasonal capture records. Bull. Yamagata Agric. Exp. Stn., 22: 77-103. (In Japanese with English summary)

Garrido, A., A. Lacasa and J. M. Rivero del, 1979. Light-traps at the service of entomological research. Intrinsic and extrinsic factors that qualitatively and quantitatively influenced the catches and the species of Lepidoptera taken in ricefields in 1975. Ann Inst. Nac.Inv.Agr., Pmt. Veg., (10): 105-126. (In Spanish)

Gyotoku, N., 1990. Lepidoptera attracted at a light trap in Tsukushini-shi, Fukuoka. 1. Brachinidae, Saturniidae and Sphingidae. Kitukyushu no Konchu, 37: 7-12. 4 tables. (In Japanese)

Hagen, A. F., 1976. A fourteen-year summary of light trap catches of the western bean cutworm in Nebraska Loxagrotis albicosta (Smith) (Lepidoptera: Noctuidae). J. Kansas Ent. Soc., 49: 537-540.

Ishitani, M., 1996. Ecological studies on ground beetles (Coleoptera: Carabidae. Brachinidae) as environmental indicators. Misc. Rep. Hiwa Mus. Nut. Hist.. 34: 1 110. (In Japanese with English summary)

Ishitani, M., J. Watanabe and K. Yano 1994. Species composition and spatial distribution of ground beetles (Coleoptera) in a forage crop field. Jpn.J. Ent., 62: 275-283.

Ishitani, M., T. Tsukamoto, K. Ikeda, K. Yamakawa and K. Yano Fauna1 and biological studies of ground beetles (Coleoptera: Carabidae, Brachinidae) (I). 
Species compositions on river banks in the same river system. Jpn.J. Ent. (submitted)

Landin, J., 1968. Weather and diurnal periodicity of flight by Helophorus vrevipalpis Bedel (Col., Hydrophilidae). Opusc. Ent., 33: 28-36.

Larochelle, A., 1973. Ground-beetles flying under an electric light (Coleoptera: Carabidae). Proc. ent. Soc. Wash., 75: 424-427.

Lövei, G. L. and K. D. Sunderland, 1996. Ecology and behavior of ground beetles (Coleoptera: Carabidae). Ann. Rev. Ent., 41: 23 1-256.

Luff, M. L., 1973. The annual activity pattern and life cycle of Pterostichus maidus (F.) (col. Carabidae). Ent. Scand., 4: 259-273.

Luff, M. L., 1980. The biology of the ground beetle Harpalus rufipes in a strawberry field in Northumberland. Ann. appl. Biol., 94: 153- 164.

Luff, M. L., 1982. Population dynamics of Carabidae. Ann. appl.Biol., 101: 164170.

Luff, M. L., 1987. Biology of polyphagous ground beetles in agriculture. Agric.Zool. Rev., 2: 237-278.

Miyashita, K., 1971. Recent status of the rice stem borer, Chilo suppressalis Walker. in Japan. In: Symposium on rice insects. Trop. Agr. Res. Ser., TARC, 5: 169-176.

Nakamura, S., 1981. Occurrence of Saturniidae caught by a light trap in Takano-cho (1966-1973). Hiroshima Mushinokai Kaiho, 20: 373-377. (In Japanese)

Shimaji, I., 1973. Researches on the annual trend of coleopterous insects caught by light trap in Hirakura University Forest. I. Annual trend of scarabaeid insects population during 6 years (1966-1971). Bull. Mie Univ. For., (8): 9-17. (In Japanese)

Shimaji, I., 1974. Ditto. II. Annual trend of lucanid insects population during six years (1966-1971). Bull. Mie Univ. For., (9): 1-8. (In Japanese)

Tanaka, K., 1988. Coleoptera. In: The Insects of Yamaguchi Prefecture. Spec. Pub. Yamaguchi Museum. 197 pp., 332 pls. (In Japanese)

Thiele, H. U., 1977. Carabid Beetles in Their Environments. xvii+369 pp. SpringerVerlag, Berlin, Heidelberg, New York.

Vanhercke, L., J.-P. Maelfait and K. Desender 1981. Beetles captured by means of a light trap. Biol. Jahrb. Dodonaea, 48: 153- 162.

van Huizen, T. H. P., 1979. Individual and environmental factors determining flight in carabid beetles. Misc. Pap., Landbouwhoogeschool Wageningen, 18: 199-2 11.

Williams, C. B., 1939. An analysis of four years captures of insects in a light trap. Part 1. General survey; sex proportion; phenology; and time of flight. Trans R. ent. Soc. Lond., 89: 79- 131 .

Williams, C. B., 1940. Ditto. Part II. The effect of weather conditions on insect activity: and the estimation and forecasting of changes in the insect population. Trans. $R$. ent. Soc. Lond., 90: 227-306.

Wolda, H., 1978. Fluctuations in abundance of tropical insects. Amer. Nat. 112: 1017-1045.

Wolda, H., 1980. Seasonality of tropical insects I. Leafhoppers (Homoptera) in Las Cumbres, Panama. J. Anim. Ecol., 49: 277-290.

Wolda, H., 1992. Trends in abundance of tropical forest insects. Oecologia, 89: 47-52. 
Yahiro, K., T. Hirashima and K. Yano, 1990. Species composition and seasonal abundance of ground beetles (Coleoptera) in a forest adjoining agroecosystems. Trans. Shikoku ent. Soc., 19: 127-133.

Yahiro, K., T. Fujimoto, M. Tokuda and K. Yano, 1992. Species composition and seasonal abundance of ground beetles (Coleoptera) in paddy fields. Jpn. J. Ent.. 60: $805-813$.

Yano, K., 1978. Faunal and biological studies on the insects of paddy fields in Asia. Part I. Introduction and Sciomyzidae from Asia (Diptera). Esakia.(11): l-27.

Yano, K., K. Yahiro, M. Uwada and T. Hirashima, 1989. Species composition and seasonal abundance of ground beetles (Coleoptera) in a vineyard. Bull.Fac. Agric: Yamaguchi Univ., 37: 1- 14.

Yasumatsu, K., W. Wongsiri, C. Tirawat, N. Wongsiri and A. Lewvanich. 1981. Contributions to the Development of Integrated Rice Pest Control inThailand. iv+204 pp. JICA, Tokyo. 